Studia Slavica Savariensia 2018. 1-2. 3-9

DOI: $10.17668 /$ SSS.2018.1-2.3

\author{
Даниэль Банасяк ${ }^{1}$ \\ (Лодзь, Польша)
}

\title{
ОБРАЗ ПРИРОДЫ В СТИХОТВОРЕНИЯХ ДАНИИЛА АНДРЕЕВА
}

\begin{abstract}
The article analyzes the poems of the cycles Skvoz prirodu and Bosikom, which are part of a complex structured Russian gods by Daniil Andreev. The work focuses on the main themes of the cycles - the unity of the poet with the nature of Russia. In poems conveyed a sense of spiritual freedom, that bring wandering without pragmatic goal. In the world of nature, the lyrical hero, the poet's alter ego acts as a true philosopher, who feels the presence of God. Nature is understood by him as God's Temple. Through deep insight into the nature the poet hears the revelation of the mystery of eternity and the cosmos. The world of nature is dynamic and harmonious at the same time.

Keywords: Daniil Andreev, Russian gods, poem, the image of nature, God, eternity, nature of Russia
\end{abstract}

Творчество Даниила Андреева, одной из самых загадочных и трагических фигур в истории русской литературы, мистики, философии можно отнести к т.н. «возвращенной литературе». Главными книгами писателя являются Роза мира, Железная мистерия, Русские боги. Две первые книги были завершены, последняя осталась не дописанной. В данной статье проанализируем стихотворения из «поэтического ансамбля» Русские боги, входящие в состав семнадцатой и восемнадцатой главы. Эти произведения посвящены теме природы.

Семнадцатая глава Сквозь природу включает цикл из двадцати трех стихотворений. В данном цикле доминирует тема природы в широком смысле слова - как сотворенного богом мира, как место обитания обычного человека. Теперь перейдем к анализу конкретных стихотворных текстов.

В стихотворении «Порхают ли птицы, играют ли дети...» на первый план выдвинуты онтологические темы. Лирический герой чувствует присутствие Бога в мире. Природа понимается им как Божий Храм: «Проносятся звезды в мерцаньи и пеньи, / Поля запевают и рощи цветут, / И в этом, объемлющем землю, круженьи / Я слышу: Ты рядом. Ты близко - вот тут. // ....Вся жизнь - это танец творящего Бога, А мир - золотая одежда Его (АНДРЕЕВ 2006а: 391).

${ }^{1}$ ORCID ID: https://orcid.org/0000-0001-8087-8187 
В стихотворении «Не o комбайнах...» тема обозначена так: «О просветленье эти стихи». «Просветленье» - это умение видеть и слышать природу в ее гармонии и мудрости, это интуитивное постижение всего сущего, это единение человеческой души и духов стихий «Я погружу тебя в мягкие мхи, / В марево гроз и дрожащего зноя: / Веруй со мною! / Слушай со мною / Вечное (АНДРЕЕВ 2006а: 392).

Через глубокое проникновение в природу можно услышать откровения, прикоснуться к тайнам вечности и космоса. Лирический герой указывает на «созвучность» природных явлений. Мир природы динамичен и гармоничен одновременно «Все приоткроется завтра тебе. / Дивной созвучности, / мудрой способности / Их ощущать - / твое тело полно (АНДРЕЕВ 2006а: 392).

В стихотворении обозначены и подчеркнуты онтологические и познавательные элементы мира.

Стихотворение $Я$ люблю - не о спящей иаревне... показывает любовь лирического героя к деревне, людям, которые там живут «Я люблю - в босоногой деревне / Белобрысых ребят в пыли (АНДРЕЕВ 2006а: 393).

Лирический герой ценит неприхотливый быт деревни. Его умиляют «жеребята на тоненьких ножках», «воробьи над свежим навозом», ему нравится здоровая и полноценная еда («гречиха», «молоко», «сало»), его умиротворяет природа («пышно-тихие облака»). Лирический герой через восхваление природы восхваляет самого Бога-Творца, мысля себя верным сыном Его. Деревня в художественном мире представлена поэтом идиллически.

В поэтической вселенной Андреева особое место занимает образ рек: «бессмертные души рек... / Я причастен давно их раю» (АНДРЕЕВ 2006а: 393). В стихотворении $B b l$, реки сонные... поэт соотносит реки с бездонной душой России. Сама природа хранит память о сказочных богатырях земли русской, о «доблести» князя Игоря, о «чудном Спасе». Прошлое и настоящее, история и религия сливаются в едином потоке живой памяти: «В лесной глуши горя, / Не гаснет сказ / Про доблесть Игоря, / Про чудный Спас (АНДРЕЕВ 2006а: 393-394).

В стихотворении Другие твердят о сегодняшнем дне.. Андреев определяет свою творческую позицию, которая отличается от распространенной среди современных Андрееву поэтов, занятых прославлением «сегодняшнего дня»: «Не заговорщик я, не бандит, - / Я вестник другого дня. / А тех, кто сегодняшнему кадит - / Достаточно без меня (АНДРЕЕВ 2006а: 395).

Обратим внимание на стих «Не заговорщик я, не бандит», который, на наш взгляд, семантически перекликается со строкой С. Есенина «Не злодей я и не грабил лесом» из стихотворения Я обманывать себя не стану, включенного в известный цикл Москва кабацкая. Эту перекличку можно считать интертекстуальной аллюзией. Оба поэта настаивают на своей отстраненности от сильных мира сего. 
В андреевском стихотворении поэт-вестник в равной степени устремлен к познанию прошлого и настоящего, но главная его цель будущее: «Про всенародное наше Вчера, / Про древность я говорю; / Про вечность; про эти вот вечера, / Про эту зарю (АНДРЕЕВ 2006а: 395).

Именно через постижение прошлого и настоящего поэт прозревает будущее - «солнечное, как бог», в котором хочет видеть истинный смысл человеческого бытия.

В следующем стихотворении Древнее Андреев как бы развивает одну из своих позиций, намеченных ранее: «Про древность я говорю». Древнее посвящено раскольникам (старообрядцам, приверженцам старой веры, вынужденным скрываться от преследований властей в самых глухих местах, зачастую абсолютно не тронутых цивилизацией). Для того, чтобы выжить, человек, с одной стороны, подчинялся законам природы, а с другой, тщательно их изучал, что давало ему власть над лесом. Человек становится «пастырем бора, его жрецом, его главой», воле человека «покоряются лесные божества» (АНДРЕЕВ 2006а: 396). Раскольники, скрывавшиеся в таежных лесах в течение двух веков смогли выжить только потому, что жили в полном соответствии, в гармонии с законами суровой природы. С «древностью» связано и следующее стихотворение Таится дрёмный мир сказаний. Здесь речь идет о «прозваньях старинных русских городов», таких, как Муром, Белозерск, Переяслав, Туров. В их названиях автор обнаруживает особую поэтическую этимологию: «О боре сказочном и хмуром, / О мухоморах в мягком мху / Услышишь память в слове Муром, / Приятном чуткому стиху. // Встает простор пустынный, пенный, / На побережьях - конский порск, / И город бедный, белостенный / Мне в прозвище Белоозерск» (АНДРЕЕВ 2006а: 397).

В стихотворении Когда несносен станет гам... поэт переходит от «древности» к своему настоящему. Стихотворение посвящено друзьям «семье Левенков» (т.е. семье П.П. Левенка, учителя рисования в городе Трубчевске). Автор воссоздает картину семейной идиллии, ему дороги старые патриархальные отношения в семье, почитание старших («Завидев, что явился ты - / Друг батюшки, знакомый дедушки, / Протянут влажные персты / Чуть-чуть робеющие девушки»), уважение, гостеприимство, «радушие», желание и умение вести беседу («Беседа потечет - естественна, / Как этот городок, проста, / Чистосердечна, благодейственна»). И здесь автора привлекает естественность, простота, чистосердечность человеческих отношений («Дом тих, гостей солидно слушая, / И ты, приятно говоря, / Купаешься в реке радушия»). В центре «многочадной» семьи стоит «проста, как мать», хозяйка: «Хозяйка станет занимать / И проведет через гостиную, / Любовна и проста, как мать, / Приветна ясностью старинною» (АНДРЕЕВ 2006а: 398). Семья Левенков - это образец семьи, сохранившей старинные традиции. Она дорожит доброжелательной атмосферой и открытостью своего дома, где старые и малые имеют свои права и обязанности. Поэт, описывая «свой круг» 
друзей, чувствует себя как дома. Он идеализирует деревню, маленькие «уютные городки», природу как миф естественного бытия, не искаженного городской цивилизацией.

В стихотворении Манику (согласно трактату Раза мира, Манику «слой обитания мелких стихиалей: домовых, хранителей очага», (АНДРЕЕВ 2006b: 178) Андреев в юмористическом ключе продолжает развитие темы домашнего очага.

Начиная с одиннадцатого стихотворения Стихалии Фальторы, в цикл включается тема «преддверия Заветов будущего» (АНДРЕЕВ 2006а: 400), о тайнах которого поведают «Другому веку / Его вожди (АНДРЕЕВ 2006а: 401).

Будущее - это пока «семя, «вызревающее в борозде». Но уже сейчас поэт учит своих современников «вслушиваться в голоса ветров», вдумываться в мысли людей и пропускать все через «Глубину» своего «сердца». И только тогда возникнет новый мир, «прошедший сквозь тебя и преображенный; / миф, рождающийся в миллионах сердец, / рассудком неуловимый; / лоно религии, еще не нашедшей / ни заповедей, ни пророков (АНДРЕЕВ 2006а: 412-413).

Будущий мир, к которому устремлен поэт всеми силами своей души будет мудрым, «как вековые камни великих народов» (АНДРЕЕВ 2006а: 413), добрым, «как тепло очага» (АНДРЕЕВ 2006а: 413), многолюдным и «веселым, как детские игры» (АНДРЕЕВ 2006а: 413).

В восемнадцатой главе - Босиком, представлен цикл из тридцати четырех стихотворений. Стихотворения этого цикла автобиографичны, так или иначе связаны с любовью поэта к странствиям, с его необычным навыком ходить босиком не только летом или весной, но даже зимой (ЧУКОВ 1997: 466).

Постоянными в цикле являются тема, мотив, хронотоп дороги. Дорога для поэта - это его песня, его судьба. В стихотворении Как участь эта легка... переполняющие его эмоции автор выражает обилием восклицательных знаков: «Мелькают межи, столбы, / Деревни у перелога... / Дорога! Песня-дорога! / Песня моей судьбы! (АНДРЕЕВ 2006a: 421).

В этом же стихотворении содержится и такой стих: «Дорога! Птицадорога!», вызывающий ассоциацию с гоголевской птицей-тройкой - «Не так ли и ты, Русь, что бойкая необгонимая тройка несешься?» (ГОГОЛЬ 2002: 684). Ассоциативное сближение с Гоголем свидетельствует об общности: оба поэта были обеспокоены судьбами своей родины.

В стихотворении Сколько рек в тиши лесного края... содержится мотив воды, русских рек, очищающих, не только тело, но и душу человеческую. Вода выступает в сказочных функциях - «мертвой»: омывающей тело и «живой», восстанавливающей душу: «Как светло мне, как легко и щедро / Засмеялась ты и позвала, / В плавные, качающие недра / Жаждущее тело приняла. // Пот горячий с тела омывая, / Беззаботна, радостно-тиха, / Ты 
душой своей, как реки рая, / Омывала душу от греха (АНДРЕЕВ 2006а: 424-425).

Мотив воды развивается также в стихотворении Лиурна. Заглавие отсылает к «миру стихиалей / Озер и рек», упомянутом Андреевым в Розе мира (АНДРЕЕВ 2006b: 345).

Только общение с природой во всех ее проявлениях и процесс движения способны доставить поэту мгновения неимоверного счастья: «Мгновенья новые такого счастия, / Блуждая далями, / Найду ли где, / Как свет вливающегося сопричастия / Со стихиалями / В живой воде? (АНДРЕЕВ 2006а: 425).

Темы дороги, движения, и связанные с ними различные мотивы и коннотации: погони, бродяжества, ног, следов, пяток и т.д. присутствуют в каждом из тридцати четырех стихотворений цикла. Все произведения связаны с трубчевскими впечатлениями Андреева. Алла Андреева вспоминает, что «Летом он бывал под Москвой и в Крыму, но больше всего любил уезжать в Трубчевск» (АНДРЕЕВ 2006а: 10). Жена поэта утверждает, что Андреев «уходил в многодневные пешие путешествия, почти всегда один, босой, со скудным запасом немудреной еды... Ночевал в случайном стоге сена, в лесу, на мху» (АНДРЕЕВ 2006а: 10).

Первую поездку в Трубчевск Андреев совершает в августе 1930 г. В письме брату, В. Л. Андрееву, от 25 августа - 6 сентября 1930 г. так описывает этот район:

«Живу в глуши, в маленьком городишке Трубчевске, на реке Десне. Красота тут сказочная, и я только смотрю и слушаю. Очень далеко гуляю один. Жара, я черен как уголь. Был на лесных озерах, куда еще прилетают лебеди» (АНДРЕЕВ 2006с: 176).

Через год поэт снова едет отдыхать и странствовать по чудесным окрестностям города (АНДРЕЕВ 2006с: 489, а затем летом 1932 и 1936 гг. (АНДРЕЕВ 2006с: 491). В последний раз, совсем ненадолго, по свидетельству Л.П. Левенок, поэт приехал в Трубчевск в 1940 г. (АНДРЕЕВ 2006с: 192). Впечатления от этих мест стали для Андреева инспирацией для создания стихотворений, посвященных русской природе, понимаемой как мир просветленья.

Отличительной особенностью восемнадцатой главы является ее пронизанность юмором и шуткой. В первом же стихотворении цикла Из шумных, шустрых, пестрых слов... присутствует и дорогая автору тема странничества (бродяжничества) и легкая авторская самоирония: «Ну что ж! В бродяжье божество / Любовно верить никого / Я не неволю, / Слоняюсь только да слежу / Сорок, стрижей, ручей, межу, / Курганы в поле (АНДРЕЕВ 2006а: 414).

Стихотворение $A x$, как весело разуться в день весенний! насыщено живой радостью бытия, которая возникает от «благовония дороги» (корней, перегноя, травы). Поэту дорога неприхотливая сельская 
картинка: по прохладной земле, только освободившейся от снежного покрова, «топают смеющиеся пятки» босых деревенских ребятишек.

В стихотворении Лёвушка! Спрячь боевые медали..., обращенном к историку, искусствоведу, другу и сокамернику Андреева - Льву Львовичу Ракову (1904 - 1970), поэт шутливо призывает: «К черту дела многоважные брось». Что может быть интереснее возрождения и обновления природы, когда обнажаются «древесные души»? Но этот высокий пафос моментально снижается за счет введения в текст шутливых разговорных реплик и интонаций: «Тебе лень шевелиться сегодня? Ладно. Я добр, - я тебя донесу» (АНДРЕЕВ 2006а: 416).

Поэт призывает: «Швырните ж обувь! Отриньте!» и далее почти серьезно, приводит в качестве аргументов примеры народов Индонезии, премудрой Индии, Абиссинии, Полинезии и, конечно, России, впитывающих безбрежную силу земли «на босом ходу».

В следующем стихотворении «Вот блаженство - ранью заревою» описано неимоверное удовольствие ходить босиком и чувствовать себя при этом «наперсником и любовником первозданной силы бытия» (АНДРЕЕВ 2006а: 421).

В последнем стихотворении Заключение Андреев предстает как проникновенный лирик: «Много призван вместить ты, много, / Прост как голубь и мудр как змий, / Чтоб ложилась твоя дорога / В чистоте и в любви стихий (АНДРЕЕВ 2006а: 442).

Итак, главные темы цикла - единение поэта с природой России, любовь к ее полям, лесам, рекам, озёрам, небу, солнцу. В стихотворениях передано ощущение необыкновенной духовной свободы, которую приносят скитания без прагматической цели.

Мир природы, где поэт выступает истинным философом открыт в вечность. Лирический герой чувствует присутствие Бога. Природа понимается им как Божий Храм. Через глубокое проникновение в природу поэт слышит откровения, тайны вечности и космоса. Мир природы динамичен и гармоничен одновременно. Мир будущего, к которому устремлен поэт всеми силами своей души должен быть мудрым, «как вековые камни великих народов» (АНДРЕЕВ 2006а: 413), добрым, «как тепло очага» (АНДРЕЕВ 2006а: 413), многолюдным и «веселым, как детские игры» (АНДРЕЕВ 2006а: 413).

\section{Литература}

АНДРЕЕВ 2006а = АНДРЕЕВ Д.Л. Собрание сочинений: В 4 т. Т. 1. Москва, 2006.

АНДРЕЕВ 2006b = АНДРЕЕВ Д.Л. Собрание сочинений: В 4 т. Т. 3. Москва, 2006.

АНДРЕЕВ 2006c = АНДРЕЕВ Д.Л. Собрание сочинений: В 4 т. Т. 4. Москва, 2006. 
ГОГОЛЬ 2002 = ГОГОЛЬ Н.В. Сочинения. Москва, 2002.

ЧУКОВ 1997 = ЧУКОВ Б.В. Из воспоминаний о Д. Л. Андрееве // Даниил Андреев. Собрание сочинений: В 3 т. Т. 3, кн. 2. Москва, 1997. 